\title{
Inhibition of Glucagon Release by Serotonin in Mouse Pancreatic Islets
}

\author{
J. Marco, J. A. Hedo, and M. L. Villanueva \\ Clínica Puerta de Hierro, Universidad Autónoma de Madrid, Madrid, Spain
}

Summary. In this work we have investigated the effect of serotonin on glucagon release in mouse pancreatic islets isolated by the collagenase technique.

Incubation of the islets with serotonin (4 $\times 10^{-3} \mathrm{~mol} / \mathrm{l}$ ) was associated with an inhibition of glucagon output both in the basal medium $(3.3 \mathrm{mmol} / \mathrm{l}$ glucose) and in the presence of arginine $(10 \mathrm{mmol} / \mathrm{l})$. The inhibitory effect of serotonin on basal glucagon release was also apparent at concentrations of $2 \times 10^{-3} \mathrm{~mol} / \mathrm{l}, 10^{-3} \mathrm{~mol} / \mathrm{l}$ and $5 \times 10^{-4} \mathrm{~mol} / 1$. Addition of 5-hydroxytryptophan (4 $\left.\times 10^{-3} \mathrm{~mol} / \mathrm{l}\right)$ to the incubation medium was without effect on basal glucagon output while it significantly reduced arginine-induced glucagon release. In contrast, tryptophan $\left(4 \times 10^{-3} \mathrm{~mol} / \mathrm{l}\right)$ provoked glucagon secretion. As inferred from our previous human studies, the present data indicate that serotonin is able to inhibit glucagon secretion. These findings provide further support for the participation of a serotoninergic mechanism in the control of A-cell function.

Key words: Mouse pancreatic islets, glucagon, insulin, serotonin, 5-hydroxytryptophan, tryptophan, creatinine sulphate.

In man, treatment with serotonin antagonists (cyproheptadine and methysergide) as well as with an inhibitor of serotonin synthesis (para-chlorophenylalanine) induces a potentiation of glucagon secretion. Because of these findings, we have suggested that serotonin modulates A-cell function by acting as an inhibitor [1]. To investigate this hypothesis further, in this work we have examined the effects of serotonin and its immediate precursor (5-hydroxytryptophan) on glucagon release in a preparation of isolated mouse pancreatic islets. In addition, insulin output was measured.

\section{Materials and Methods}

The preparation of pancreatic islets employed has been described in detail elsewhere [2]. Briefly, fourweek old male mice, fasted for $14 \mathrm{~h}$, were used as pancreas donors. The islets were isolated by the collagenase technique [3], as modified by Coll-García and Gill [4]. Batches of 10 islets were incubated for 60 to 120 minutes in $2 \mathrm{ml}$ of Krebs-Henseleit solution [5] (gas phase 95:5, $\mathrm{CO}_{2}: \mathrm{O}_{2}$ ), containing $0.2 \mathrm{~g} / 100 \mathrm{ml}$ bovine albumin (Cohn fraction $\mathrm{V}$ ), $2000 \mathrm{U}$ of kallikrein-trypsin inhibitor (Trasylol), and $3.3 \mathrm{mmol} / \mathrm{l}$ glucose. Conventionally, this solution will be referred to as "basal medium" throughout the text. In some experiments, arginine hydrochloride $(10 \mathrm{mmol} / \mathrm{l})$ was used as the glucagon secretagogue. Serotonin creatinine sulphate, 5-hydroxy-L-tryptophan, L-tryptophan and creatinine sulphate were added as described in the figures and text. All incubations were performed in a water bath at $37^{\circ} \mathrm{C}$, set at 60 strokes per minute.

Glucagon and insulin were measured by radioimmunoassay $[6,7]$. Results are expressed as means \pm SEM. $N$ indicates the number of independent experiments. The term experiment refers to a set of incubations performed at the same time with islets prepared from a pool of eight pancreases. Within each experiment, all factors were tested simultaneously employing from 6 to 10 incubation vials. Differences betwen values were tested for significance by Student's t-test.

Collagenase was purchased from Boehringer Mannheim $\mathrm{GmbH}$; arginine hydrochloride, seroto- 


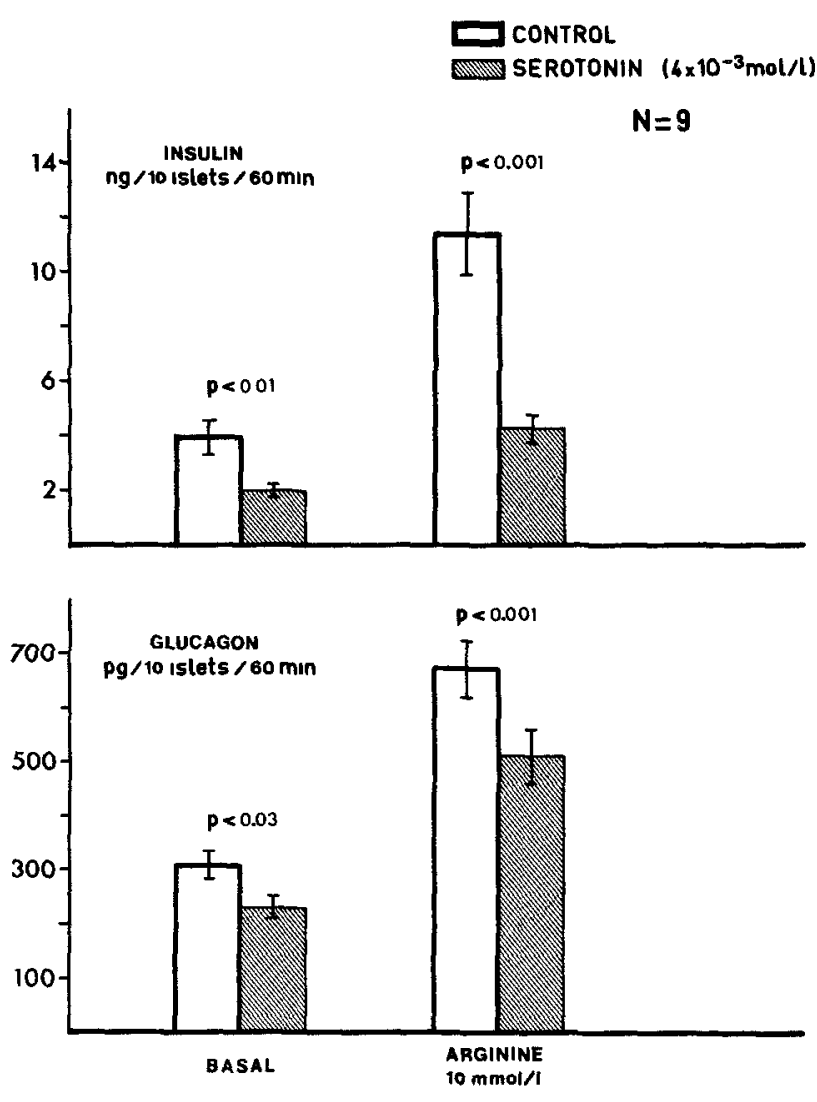

Fig. 1. Effect of serotonin on basal and arginine-induced glucagon and insulin release by mouse pancreatic islets. (Means \pm SEM. $\mathrm{N}=$ number of independent experiments)

nin creatinine sulphate, 5-hydroxy-L-tryptophan, Ltryptophan and creatinine sulphate were obtained from Sigma Chem. Co. Glucagon- $\mathrm{I}^{125}$ and insulin$\mathrm{I}^{125}$ were kindly supplied by Dr. I. Valverde. Glucagon antiserum $(30 \mathrm{~K})$ was a generous gift from Dr. R. H. Unger.

\section{Results}

As shown in Figure 1, incubation of the islets with serotonin $\left(4 \times 10^{-3} \mathrm{~mol} / \mathrm{l}\right)$ was associated with an inhibition of glucagon release, both in the basal medium and in the presence of arginine $(\simeq 25 \%$, $p<0.03$ and $p<0.001$, respectively). Addition of serotonin also produced a decrease in insulin secretion $(\simeq 49 \%, \mathrm{p}<0.01$ in the basal medium; $\approx 62 \%$, $\mathrm{p}<0.001$ in the presence of arginine).

Since serotonin was employed as a creatinine sulphate complex, we tested the effect of creatinine sulphate in our preparation. Addition of this com-
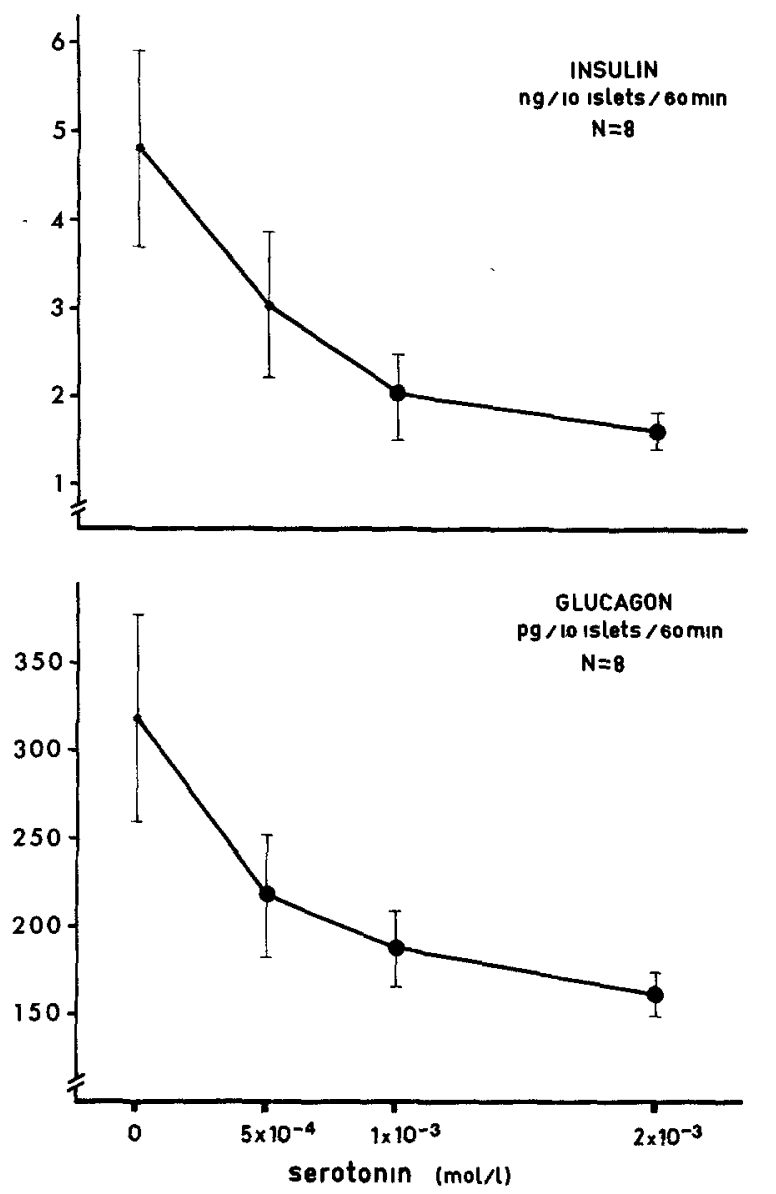

Fig. 2. Glucagon and insulin release by mouse pancreatic islets in the presence of different concentrations of serotonin in the basal medium (Means $\pm S E M$. $N=$ number of independent experiments). The large dots represent statistically significant differences from the 0 serotonin value

pound to the basal medium at $4 \times 10^{-3} \mathrm{~mol} / \mathrm{l}$ failed to modify significantly glucagon and insulin secretion, although a greater output of both hormones was observed (glucagon: $186 \pm 27$ vs. $335 \pm 68$ $\mathrm{pg} / 10$ islets $/ 60 \mathrm{~min}, \mathrm{~N}=4$; insulin: $2.6 \pm 0.8$ vs. $3.7 \pm 1.6 \mathrm{ng} / 10$ islets $/ 60 \mathrm{~min}, \mathrm{~N}=4$ ).

Figure 2 shows that serotonin, at lower concentrations than that used in the first series of experiments, also diminished basal glucagon and insulin release. This inhibition showed a dose dependent pattern. At $5 \times 10^{-4} \mathrm{~mol} / \mathrm{l}$, the lowest molarity tested, the reduction of glucagon secretion was still statistically significant $(\mathrm{p}<0.01)$, while $10^{-3} \mathrm{~mol} / \mathrm{l}$ was the minimal concentration of serotonin required to inhibit significantly insulin output $(p=0.03)$.

The presence of 5-hydroxytryptophan (the immediate precursor of serotonin) in the medium (Fig. 3), did not affect basal glucagon release; however, it caused a clear decrease in arginine-induced glucagon secretion $(\simeq 34 \%, \mathrm{p}<0.0001)$. 5-Hydroxytryptophan also inhibited arginine-stimulated 


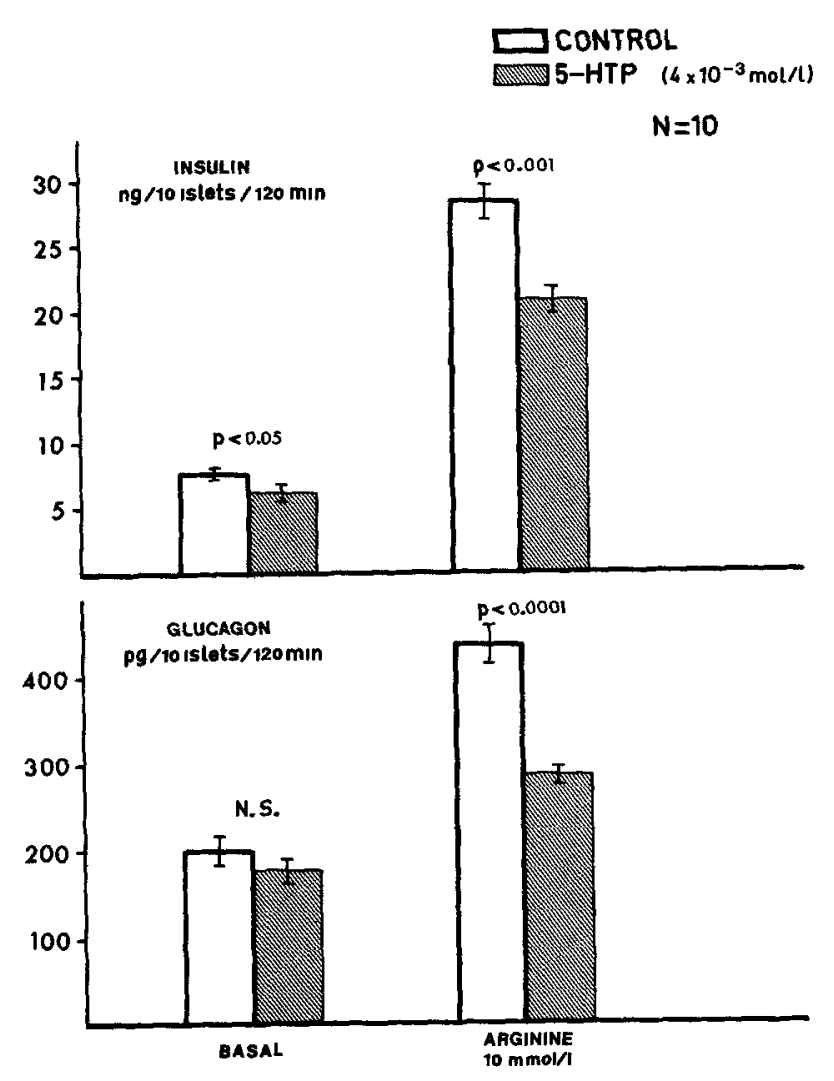

Fig. 3. Effect of 5-hydroxytryptophan on basal and arginıne-1nduced glucagon and insulin release by mouse pancreatic islets (Means \pm SEM. $\mathrm{N}=$ number of independent experıments)

insulin release $(\simeq 26 \%, \mathrm{p}<0.001)$; a small but significant decrease of basal insulin output $(\simeq 17 \%$, $\mathrm{p}<0.05$ ) was found.

Finally, tryptophan (the essential amino acid from which serotonin is derived) at $4 \times 10^{-3} \mathrm{~mol} / 1$ provoked glucagon secretion $(292 \pm 41$ vs. $591 \pm 118 \mathrm{pg} / 10$ islets $/ 60 \mathrm{~min}, \mathrm{~N}=9, \mathrm{p}<0.05)$.

\section{Discussion}

The foregoing data indicate that serotonin behaves as an effective inhibitor of glucagon release in mouse pancreatic islets. This action cannot be attributed to the presence of creatinine sulphate in the serotonin complex tested since, in our preparation, this substance fails to modify significantly hormone output.

It is obvious that the concentrations of serotonin employed in our incubations can hardly be applied to physiological conditions. However, they are well within the range described for inhibition of insulin release by the pancreas of several species $[8,9,10]$.

5-Hydroxytryptophan did not affect glucagon release when added to the basal medium, although it significantly reduced arginine-stimulated glucagon output. Since mouse pancreatic A-cells are able to store serotonin after 5-hydroxytryptophan administration [11], the inhibition of glucagon secretion by this amino acid could be attributed to its conversion to serotonin; nevertheless, a direct effect cannot be excluded. It should be mentioned that exposure of the islets to 5-hydroxytryptophan was maintained for 120 minutes since, as reported by Gylfe et al. [12], the uptake of this substance by pancreatic islets of obese mice reaches a steady state after one $h$ of incubation. In contrast, tryptophan displayed glucagonotropic activity, which is in accordance with the stimulation of glucagon secretion induced by this amino acid in dog [13] and in man [14]. On the other hand, no conversion of tryptophan to 5-hydroxytrytophan or to serotonin was found by Gylfe and associates in their "in vitro" preparation [12].

Hence, the present results lend support to the inhibitory action of serotonin on A-cell secretion, as inferred from our previous human studies [1].

Concerning insulin release, our findings confirm the inhibitory effect of serotonin described by Feldman et al. in pieces of hamster, rabbit and mouse pancreas $[8,9,10]$ and extend the observations of these authors to another B-cell stimulus; i.e., arginine. The reduction of arginine-stimulated insulin release observed in the presence of 5-hydroxytryptophan, is in good agreement with previous "in vitro" and "in vivo" data obtained in rabbits and mice $[15,16,17]$. As in the case of its effect on A-cell function, the conversion of this substance to serotonin within the B-cell [12] seems to be a plausible explanation for its inhibitory action on insulin secretion.

Acknowledgements The expert technical assistance of Ms Begoña Samper, Ms. Ana Ramírez and Ms. Pilar García is gratefully appreciated.

This work has been in part supported by a research grant (12-317-76) from the Instituto Nacional de Previsión, Spain; by a research contract (No. 1551/RB) from the International Atomic Energy Agency, Vienna, Austria; and by a gift from the Alexander von Humboldt Stiftung, Bonn-Bad Godesberg, Federal Republic of Germany.

\section{References}

1. Marco, J., Hedo, J A., Martinell, J, Calle, C, Villanueva, M.L. Potentiation of glucagon secretion by serotonin antagonists in man J. Clin. Endocrinol. Metab 42, 215-221 (1976) 
2. Marco, J. Calle, C., Hedo, J. A., Villanueva, M. L.: Enhanced glucagon secretion by pancreatic islets from prednisolonetreated mice. Diabetologia 12, 307-311 (1976)

3. Lacy, P E., Kostianovsky, M.: Method for the isolation of intact islets of Langerhans from the rat pancreas. Diabetes 16, 35-39 (1967)

4. Coll-García, E., Gill, J.R.: Insulin release by isolated pancreatic islets of the mouse incubated "in vitro" Diabetologia 5, 61-66 (1969)

5. Krebs, H. A., Henseleit, K.: Untersuchungen uber die Harnstoffbildung im Tierkorper. Hoppe Seylers Z. Physiol. Chem. 210, 33-66 (1932)

6. Faloona, G R., Unger, R.H.: Glucagon. In: B.M. Jaffe, H.R. Behrmann (eds.): Methods of hormone radioimmunoassay, pp. 317-330. New York: Academic Press, Inc. 1974

7. Herbert, V., Lau, K.-S., Gottlieb, C.W., Bleicher, S.J.: Coated charcoal immunoassay of insulin. J. Clin. Endocrinol. Metab. 25, 1375-1384 (1965)

8. Feldman, J. M., Lebovitz, H. E.: Serotonin inhibitıon of in vitro insulin release from golden hamster pancreas Endocrinology 86, 66-70 (1970)

9. Feldman, J.M., Quickel, K.E., Jr., Lebovitz, H. E.: Potentiation of insulin secretion in vitro by serotonin antagonists. Diabetes 21, 779-788 (1972)

10. Quickel, K.E., Jr., Feldman, J. M., Lebovitz, H.E.: Inhibition of insulin secretion by serotonin and dopamine: species variation. Endocrinology 89, 1295-1302 (1971)

11. Ekholm, R., Ericson, L.E., Lundquist, I.: Monoamines in the pancreatic islets of the mouse. Subcellular localization of 5- hydroxytryptamine by electron microscopy autoradiography. Diabetologia 7, 339-338 (1971)

12. Gylfe, E., Hellman, B., Sehlın, J , Täljedal, I.-B.: Amino acid conversion into 5-hydroxytryptamine in pancreatic B-cells. Endocrinology 93, 932-937 (1973)

13. Rocha, D.M., Faloona, G.R., Unger, R.H.: Glucagonstimulating activity of 20 amino acids in dogs. J. Clin. Invest. 51, 2346-2351 (1972)

14. Hedo, J. A., Villanueva, M. L., Marco, J.. Elevation of plasma glucose and glucagon after tryptophan ingestion in man. Metabolism (in press) (1977)

15. Lernmark, A.: The significance of 5-hydroxytryptamine for insulin secretion in the mouse. Horm. Metab. Res. 3, 305-309 (1971)

16 Tjalve, H.: Catechol- and indolamines in some endocrine cell systems. Acta Physiol. Scand. (Suppl.) 360, 5-122 (1971)

17. Lundquist, I.: Insulin secretion. Its regulation by monoamines and acid amyloglucosidase. Acta Physiol Scand [Suppl.] 372, 9-47 (1971)

Received March 17, 1977, and in revised form:

June 9, 1977

Dr. J. Marco

Clínica Puerta de Hierro

Universidad Antónoma de Madrid

San Martin de Porres, 4

Madrid 35

Spain 